\title{
Aplicación del diseño estadístico de mezclas para la formulación de pasta autocompactante
}

\author{
Application of experimental plans method to formulate \\ a self compacting cement paste
}

\author{
A. Mebrouki ${ }^{(*)}$, N. Belas ${ }^{(*)}$, J. Viña(**), A. Argüelles ${ }^{(* * *)}$, R. Zenasni(****)
}

Recepción/Received: 17-VI-08

Aceptación/Accepted: 4-III-09

Publicado online/Online publishing: 19-V-10

RESUMEN

En este trabajo se estudia la constitución de una pasta autocompactante a base de materiales locales argelinos (cemento binario de base puzolánica natural de Beni Saf y filler calizo de cantera). La reología de la pasta se estudia en función de las dosificaciones de cemento, caliza, superplastificante y agua. La fluidez de las pastas así formadas se deducen de los ensayos de escurrimiento del mini cono y del tiempo de flujo en el cono de Marsh. Utilizando el diseño estadístico de mezclas, el número de ensayos se ha visto considerablemente reducido, el problema se transformó en ecuaciones y después se resolvió numéricamente. A partir de las curvas de los diagramas ternarios, uniendo las respuestas de escurrimiento y el tiempo de flujo de las pastas en función de las dosificaciones en constituyentes y estudiando las funciones de conveniencia para cada respuesta, se terminará por deducir una composición de pasta autocompactante.

Palabras clave: propiedades reológicas, diagramas ternarios, diseño estadístico de mezclas, pasta de cemento autocompactante.

\section{SUMMARY}

The self-compacting concrete formulation means to elaborate a self-compacting cement paste to which will be injected aggregates. The purpose of this work is to find the composition of this cement paste containing local materials (pozzolanic cement, limestone fillers, superplasticizer and water) having self-compacting properties. The use of the experimental plans method shows that it is possible to delimit an experimental field bounded by the volumetric proportions of materials composing the paste. The field was transformed in equations form conditioned by implicit constraints, defining zones of minimal shearing threshold and maximum viscosity; numerical resolution submitted to the optimization criteria permitted to define the volumetric proportions of each mixing parameter contributing to the preparation of an optimal paste. After experimental checking to validate obtained results, conclusions are that, from results given by ternary diagrams and desirability's functions, a composition of an optimal self-compacting cement pas was obtained.

Keywords: rheological properties, ternary diagrams, miscellanies plans method, self-compacting cement paste.

\footnotetext{
(*) Universidad de Mostaganem, Argelia.

(**) Universidad de Oviedo, España.

(***) Universidad de Oviedo, España.

$(* * * *)$ Universidad de Mostaganem, Argelia
} 


\section{INTRODUCCIÓN}

Como punto de partida se ha de aceptar que el hormigón está compuesto de una fase fluida (pasta) y una fase sólida (cociente entre grava y arena fijo). Las propiedades autocompactantes del hormigón derivan necesariamente de la pasta, de ahí que los estudios de formulación se basen, esencialmente, en la pasta y sus constituyentes. El método utilizado que ha dado unos resultados concluyentes con los materiales del Laboratorio de Materiales de Construcción (L.M.D.C-INSA-UPS) de Toulouse (Francia), será aplicado a los materiales locales argelinos para conseguir una formulación de pasta autocompactante, con la diferencia de utilizar un material más simple al no tener la posibilidad de emplear instrumentos más sofisticados, no necesariamente disponibles en laboratorios con un presupuesto modesto. Se han ido variando los parámetros de composición de las pastas y realizando mediciones con el mini cono y el cono de Marsh, permitiéndose así eliminar todas las composiciones no deseadas (presentaban segregaciones y no eran capaces de fluir adecuadamente); con el resto, se diseñó un trabajo experimental. Midiendo los diámetros de escurrimiento y el tiempo de flujo, se elaboraron los diagramas ternarios para delimitar las zonas de resistencia mínima y de alta viscosidad; se determinaron para estas zonas las proporciones volumétricas de los componentes de la pasta, y después se trataron numéricamente con el fin de obtener una composición óptima de la pasta.

\section{ELABORACIÓN DE PASTAS DE CEMENTO}

\subsection{Materiales y método}

El principal parámetro para la elección de estos materiales es su abundante disponibilidad y su moderado coste. El cemento utilizado es un CPJ-CEMII/A-P según la norma francesa NF P 15-301 y la norma europea EN 197-1 2000 , conteniendo menos de un $20 \%$ de puzolana natural añadida durante la molienda del clínker. El filler es de piedra caliza que se extrae de la cantera de Kristel (Orán, este de Argelia). La Tabla 1 presenta las especificaciones físicas de estos dos fillers, mientras que la Tabla 2 muestra los análisis químicos de esta adición y de la piedra caliza utilizada. En la Tabla 3, se presenta porcentualmente la composición del clínker según Bogue; clínker con la cual se ha fabricado el cemento.

\section{INTRODUCTION}

On the basis of the principle which a concrete is composed of a liquid phase (paste) and of a solid phase (aggregates with fixed gravel/sand ratio), the selfcompacting properties of the concrete necessarily come from those of the paste. For that, the studies of formulations are based primarily on the paste and its components. The method used obtained concluding results with materials from the Building Materials Laboratory (L.M.D.C-INSA-UPS, Toulouse, France), it will be applied to Algerian local materials to lead simply to a formulation of a self compacting cement paste, with the difference to use simpler material without having recourse to complicated instruments not necessarily available in laboratories with modest budget. While varying pastes composition parameters, measurements with mini-cone and Marsh cone, allowed eliminating all non-desired compositions (presenting segregation, not being able to flow or badly proportioned); with the remainder, an experimental field was formed. By measurement of the spreading out diameters and flow times, ternary diagrams were elaborate in order to delimit zones of low shear strengths and high viscosity; for these zones volumetric proportions of the paste components were retained, and then treated numerically to obtain a composition of optimal paste answering the criteria of the self-compacting properties.

\section{CEMENT PASTE ELABORATION}

\subsection{Materials and method}

The principle of choice of these materials is their abundant availability and their moderate cost. Cement used is a CPJ- CEMII/A-P within the meaning of French standard NF $P$ 15-301 and of European standard ENV 197-1 2000, containing less than $20 \%$ of natural pozzolan added at the time of the crushing of the clinker, fillers are of limestone nature and resulting from the west Algerian career. "Table 1" gives the physical specifications of these two powders, while Table 2 shows the chemical analysis of this composition. In Table 3, the mineralogical analysis of the cement clinker is presented according to Bogue.

Tabla 1 / Table 1

Propiedades físicas del cemento y de la caliza.

Physical properties of cement and limestone filler.

\begin{tabular}{|c|c|c|c|}
\hline & $\begin{array}{c}\text { Masa volumétrica / } \\
\text { Density }\left[\mathrm{kg} / \mathbf{m}^{3}\right]\end{array}$ & $\begin{array}{l}\text { Área específica / Specific surface } \\
{\left[\mathrm{cm}^{2} / \mathrm{g}\right]}\end{array}$ & $\begin{array}{c}\text { Diámetro medio D50 / } \\
\text { Average diameter D50 [ } \mathrm{\mu m}]\end{array}$ \\
\hline Cemento / Cement & 3150 & 3400 & $18.5 \mu \mathrm{m}$ \\
\hline Piedra caliza / Limestone & 2800 & 2880 & $21.2 \mu \mathrm{m}$ \\
\hline
\end{tabular}


Tabla 2 / Table 2

Análisis químicos del cemento y de la caliza (porcentajes en peso).

Chemical analysis of cement and limestone filler (percentages in weight).

\begin{tabular}{|c|c|c|c|c|c|c|c|c|c|c|}
\hline & $\mathbf{S i O}_{\mathbf{2}}$ & $\mathbf{A l}_{\mathbf{2}} \mathbf{O}_{\mathbf{3}}$ & $\mathbf{C a O}$ & $\mathbf{M g O}$ & $\mathbf{N a}_{\mathbf{2}} \mathbf{O}$ & $\mathbf{K}_{\mathbf{2}} \mathbf{O}$ & $\mathbf{F e}_{\mathbf{2}} \mathbf{O}_{\mathbf{3}}$ & $\mathbf{S O}_{\mathbf{3}}$ & $\begin{array}{c}\mathbf{C a O}_{\text {libre / }} \\
\mathbf{C a O}\end{array}$ & $\begin{array}{c}\text { Pérdida al fuego / } \\
\text { Fire loss }\end{array}$ \\
\hline Cemento / Cement & 23 & 5.7 & 60.9 & 0.7 & 0.3 & 0.4 & 3.3 & 3.4 & 0.09 & 2.1 \\
\hline Caliza / Limestone & 0.7 & 0.2 & 56.8 & 0.5 & 0.08 & 0.1 & 0.9 & - & - & 41.2 \\
\hline
\end{tabular}

Tabla 3 / Table 3

Análisis mineralógico del clínker de cemento (porcentajes en peso).

Mineralogical analysis of the cement clinker (percentages in weight).

\begin{tabular}{|c|c|c|c|c|}
\hline & $\mathbf{C}_{3} \mathbf{S}$ & $\mathbf{C}_{\mathbf{2}} \mathbf{S}$ & $\mathbf{C}_{\mathbf{3}} \mathbf{A}$ & $\mathbf{C}_{\mathbf{4}} \mathbf{A F}$ \\
\hline Cemento / Cement & 58.7 & 16.4 & 8.1 & 9.2 \\
\hline
\end{tabular}

La Figura 1 muestra los análisis mineralógicos de la piedra caliza obtenidos por difractometría de rayos $X$ (DRX). El análisis ha mostrado una composición mayoritaria de calcita del orden del $97 \%$, con indicios de cuarzo y dolomita.
Figure 1 shows filler mineralogical analysis obtained by $X$-rays (XRD). This analysis showed a majority composition of calcite (about 97\%), with dolomite and quartz traces.

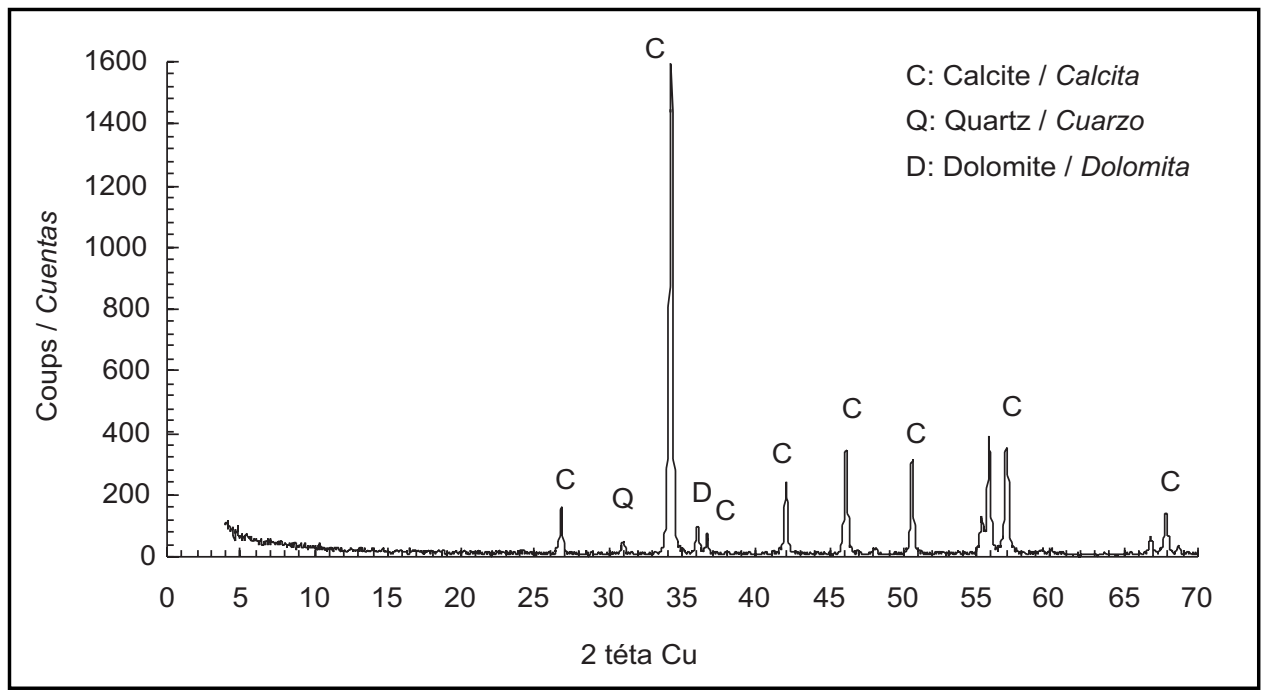

Figura 1. Análisis mineralógico de piedra caliza por DRX. Figure 1. Mineralogical analysis of filler by XRD.

El superplastificante utilizado es un Viscocréte 20HE proporcionado por SIKA-Argelia. Es un producto no clorado formado a base de un copolímero acrílico en forma líquida, conteniendo un $40 \%$ de extracto seco, de densidad $1.085 \mathrm{~g} / \mathrm{cm}^{3}$ y un $\mathrm{pH}$ de 4,5 . Se ha demostrado en diferentes estudios (1-2) que es posible elaborar algunos hormigones autocompactantes sin el uso de un agente plastificante. Para valorar los materiales locales, este parámetro no será utilizado durante la preparación de las pastas de cemento.

Se ha utilizado un mini cono inspirado en el cono de Abrams cuyas dimensiones son proporcionales (3-5) a
Superplasticizer used is "Viscocrete $20 \mathrm{HE}$ " provides by SIKA-Algeria, it is a product not chlorinated containing acrylic copolymer in liquid form, containing $40 \%$ of dry extract, density 1085 and $\mathrm{pH}$ being worth 4.5. Like was shown in several studies (1-2), it is possible to prepare self-compacting concretes without using viscosity agent; in order to remain in the context of the valorization of local materials, this parameter will not be integrate in the preparation of the cement pastes.

For measurements, a mini cone inspired of the slump test and whose dimensions are proportional to it (3-5) 
éste. El ensayo con mini cono fue inicialmente utilizado por Kantro (3), después fue modificado por Zhor y Bremner (6) y mide la consistencia de la pasta de cemento. El mini cono es simplemente una versión reducida del cono de Abrams. Las medidas del mini cono son un diámetro inferior de $19 \mathrm{~mm}$, de un diámetro superior de $38 \mathrm{~mm}$ y una altura de $57 \mathrm{~mm}$. Para el ensayo, se coloca el cono en el centro de una chapa de metal o de vidrio sobre la que se trazan las diagonales y las medianas. Una vez vertido el material y transcurrido un tiempo de un minuto, se levanta el cono, se calcula el diámetro medio de escurrimiento de la pasta, a lo largo de las dos diagonales y las dos medianas. Zhor y Bremner (6) modificaron el dispositivo para medir de manera más eficaz los efectos del aire y del plastificante en la mezcla de la pasta del cemento. Los resultados de los ensayos en mini cono se pueden relacionar con la resistencia a cortante máxima. La investigación dirigida por Ferraris, Obla, y Hill (7) sobre la influencia de las mezclas minerales en la reología de la pasta de cemento, demostró una pobre correlación entre los resultados del mini cono y la resistencia a cortante. El ensayo mediante el cono de Marsh (8), Ferraris et al. (7) es un ensayo no normalizado utilizado para cuantificar la capacidad de fluir el cemento. El cono de Marsh es un embudo de cuello largo, de $5 \mathrm{~mm}$ de orificio.

El mini cono sirve especialmente para la determinación de los diámetros de escurrimiento sobre una chapa metálica horizontal en función de los parámetros de composición (cociente agua/aglomerante, piedra caliza/aglomerante, superplastificante, etc.). Estos diámetros se miden tras un minuto de escurrimiento, siendo el procedimiento aplicado para todas las mezclas el mismo. Generalmente, existe una cierta correlación del ensayo con la resistencia a cortante (4), los resultados obtenidos con el mini cono están relacionados, en ciertos casos, con el límite de comienzo de flujo (7). La principal ventaja de este ensayo es la facilidad de ponerlo en práctica puesto que se necesita poca preparación y una pequeña cantidad de materiales (volumen inferior a $40 \mathrm{ml}$ ). Los ensayos son reproducibles y, a menudo, utilizados en América del Norte, por ejemplo, para la determinación del punto de saturación en superplastificante de una mezcla cementicia (4). Los resultados de Van K. Bui (9), muestran que el modelo reológico de la pasta puede emplearse en el diseño de mezclas SCC y reduce el trabajo intensivo en el laboratorio, el tiempo de ensayo y los materiales empleados. Estudiando la pasta de cemento, sería posible prever el comportamiento del hormigón constituido con ella (8).

Para la determinación de la fluidez de la pasta de cemento, se utiliza un cono de Marsh con objeto de medir los tiempos de flujo de un volumen de referencia de pastas de diferentes composiciones. Se trata de medir el tiempo empleado por la pasta de cemento para fluir por gravedad a través del cono rellenando un volumen de referencia was used. The mini cone test, which was originally developed by Kantro (3) and later modified by Zhor and Bremner (6), measures the consistency of cement paste. The mini-slump cone is simply a small version of the Abrams cone. The mini-slump cone has a bottom diameter of $38 \mathrm{~mm}$, a top diameter of $19 \mathrm{~mm}$, and a height of $57 \mathrm{~mm}$. The cone is placed in the center of a square piece of metal (or glass) on which the diagonals and medians are traced. The cone is lifted and after one minute, the average spread of the paste, was measured along the two diagonals and two medians, is recorded. Zhor and Bremner (6) modified the device in order to measure more effectively the air entraining and plasticizing effects of admixtures on cement pastes. Like the conventional slump test, the results of the minislump test should be related to yield stress. Research conducted by Ferraris, Obla, and Hill (7) into the influence of mineral admixtures on the rheology of cement paste showed poor correlation between the results of the mini cone test and shear stress, as measured with a sophisticated, laboratory grade parallel plate rheometer. The Marsh cone test (8), Ferraris et al. (7) is a non-standard test most typically used for oil well cements. The Marsh cone is a funnel with a long neck and an opening of $5 \mathrm{~mm}$.

It will be used primarily for the determination of the spreading out diameters on a horizontal metal plate according to mix parameters variation (water/binder ratios, limestone/binder, superplasticizer), these diameters are measured after 1 minute of spreading out, the same procedure is respected for all the mixtures. Generally, there is a certain correlation of the test with the threshold of shearing or with apparent viscosity to weak speed gradient (4), the mini-slump test results correlate in certain cases with the shear stress (7). The principal advantages of this test are the facility of its implementation since it requires little preparation and small quantity of materials (volume lower than $40 \mathrm{ml}$ ). Tests are reproducible and often used in North America for determination of superplasticizer saturation point of a cementing mixture (4). The results of Van K. Bui (9) show that the paste rheology model is useful in designing SCC mixtures and reducing the extent of laboratory work, testing time, and materials used. It would be more interesting to study the flow of the concrete by the study on cement paste which constitutes it. It is the case of the study made (8).

For consistence determination, a Marsh cone is used to measure the times of out-flows of a referential volume of pastes with different compositions. It is therefore about measuring the time of out-flow of the cement paste through the cone flowing out under gravity to fill a volume with given reference $(150 \mathrm{ml}$ in this study). As 
(150 $\mathrm{ml}$ en este estudio). Al tratarse de un volumen pequeño, la complejidad y la duración del ensayo son menores (5). Según Ferrara (10), las propiedades reológicas de hormigón pueden ser deducidas a partir de las de la pasta.

\subsection{Composición de la pasta de cemento}

La Tabla 4 presenta las composiciones de las diferentes pastas sobre las que se ha medido el escurrimiento y los tiempos de flujo. Las composiciones mostradas en la Tabla 5 tienen en cuenta las posibles variaciones capaces de contribuir a la confección de las pastas. El porcentaje de componentes (cemento + piedra caliza) se mantiene constante y la cantidad máxima de superplastificante recomendada por el fabricante es del $3 \%$. the tested volume is small, the test complexity is low and its duration short (5). As shown in Ferrara (10) study, rheological properties of the concrete can be deduced from those of the paste which forms it.

\subsection{Cement paste composition}

Table 4 gives the compositions of the various pastes on which measurements of spreading out and times of flow were carried out. The compositions showed in Table 5, as broad as they are, hold account all possible mix parameters variations which can contribute to elaborate the pastes. The quantity of the binder (cement + filler) is maintained constant, superplasticizer maximum proportioning (3\%) is recommended by manufacturing.

Tabla 4 / Table 4

Composición de las pastas estudiadas.

Composition of the studied pastes.

\begin{tabular}{|c|c|}
\hline Cemento (C) [\%] / Cement [\%] & $100-95-90-85-80-75-70-60$ \\
\hline Piedra caliza en sustitución del cemento (F) [\%] / Limestone in substitution to the cement [\%] & $0-5-10-15-20-25-30-40$ \\
\hline Agua / (cemento C + piedra caliza F) (E/L) [\%] / Water / Binder (E/L) [\%] & $0.22-0.24-0.30-0.40$ \\
\hline Superplastificante (Sp) [\%] / Superplasticizer (Sp) \% & $0-0.5-1-1.2-1.3-1.5-2-3$ \\
\hline
\end{tabular}

La Tabla 5 muestra el procedimiento experimental para la preparación de pastas de cemento.
Table 5 gives the experimental procedure followed for preparation cement pastes.

Tabla 5 / Table 5

Procedimiento experimental estándar de preparación de pasta.

Experimental procedure of preparation of a standard paste mixture.

\begin{tabular}{|c|c|c|c|c|}
\hline Etapa / Stage & $\begin{array}{l}\text { Momento / } \\
\text { Moment }\end{array}$ & $\begin{array}{l}\text { Tiempo total / } \\
\text { Total duration }\end{array}$ & $\begin{array}{l}\text { Parámetro medido / } \\
\text { Sizes measured }\end{array}$ & Resultado / Result \\
\hline $\begin{array}{c}\text { Preparación de materiales / } \\
\text { Preparation of materials and weighing }\end{array}$ & - & $10 \mathrm{~min}$. & $\begin{array}{l}\text { Masa del material / } \\
\text { Materials masses }\end{array}$ & $\begin{array}{c}\text { Dosificación / } \\
\text { Components dosage }\end{array}$ \\
\hline Mezcla de materiales / Mixture of materials & - & $5 \mathrm{~min}$. & - & - \\
\hline $\begin{array}{l}\text { Aspecto visual con la paleta / } \\
\text { Visual aspect with the trowel }\end{array}$ & - & During mixing & - & $\begin{array}{c}\text { Aspecto de la pasta / } \\
\text { Paste aspect }\end{array}$ \\
\hline $\begin{array}{l}\text { Medidas con el mini cono / } \\
\text { Measure with the mini-cone }\end{array}$ & $\begin{array}{c}t_{0}: \text { final de mezcla / } \\
t_{0}: \text { end of mixing }\end{array}$ & $2 \mathrm{~min}$. & Fluidez / Flow & $\begin{array}{l}\text { Escurrimiento }(\mathrm{cm}) / \\
\text { Spreading out }(\mathrm{cm})\end{array}$ \\
\hline $\begin{array}{l}\text { Aspecto visual en tubo de vidrio / } \\
\text { Visual aspect with glass tube }\end{array}$ & $t_{0}$ & $5 \mathrm{~min}$. & - & $\begin{array}{l}\text { Consistencia/sedimentación / } \\
\text { Consistency/sedimentation }\end{array}$ \\
\hline $\begin{array}{l}\text { Medidas con el cono de Marsh / } \\
\text { Measure with Marsh cone }\end{array}$ & $t_{0}+2 \min$ & $1 \mathrm{~min}$. & $\begin{array}{l}\text { Tiempo de fluidez / } \\
\text { Flow time }\end{array}$ & Tiempo(s) / Time (s) \\
\hline
\end{tabular}

\section{RESULTADOS Y DISCUSIONES}

Los resultados obtenidos tienen en cuenta las desviaciones calculadas para una mezcla de pasta elegida y repetidos hasta tres veces.

\subsection{Consistencia: aspecto visual}

El aspecto visual (Figura 2) es una etapa preliminar pero importante, que permite verificar visualmente la validez de la mezcla. La mezcla de pasta puede ser seca y dura

\section{RESULTS AND DISCUSSIONS}

The results selected hold account of the standard deviations calculated for paste mixtures and repeated three times under the same experimental conditions. The standard deviation will be considered the same one for all mixtures.

\subsection{Consistency: visual aspect}

The visual aspect (Figure 2) is a preliminary but important stage, it makes possible to check the validity of the mixture visually. Paste mixture can be dry or very 
(Figura 2a), cuando se confecciona con una cantidad de agua insuficiente y una tasa de piedra de caliza incorporada importante $(\mathrm{F}$ (piedra caliza) $=30 \%$ y $\mathrm{E}$ (agua)/L(cemento + piedra caliza) $=0,22$ ). En la Figura $2 \mathrm{~b}$, la pasta está formada pero no puede fluir. Por el contrario, en otros casos se constató que la pasta puede fluir pero presenta una capa blanca (Figura 2c), sinónimo de segregación entre la fase sólida y la fase líquida que constituye la pasta. También puede darse la situación de que la pasta esté bien formada pero la segregación pueda observarse mediante la medida del diámetro de escurrimiento y la aparición de burbujas. La Figura 2d muestra una mezcla bien formada y homogénea, obtenida con unas medidas de los diámetros de escurrimiento y un tiempo de flujo determinados. El mismo procedimiento será aplicado durante la experimentación, pero únicamente las mezclas que no presenten ninguna anomalía serán utilizadas para las medidas. firm (Figure 2a), when that is made with insufficient water/binder ratio $(E / L=0.22)$ and an important filler substitution quantity $(F=30 \%)$. In the Figure $2 b$, the paste is formed but plastic, not being able to flow. Contrary to the preceding one, it was noted a paste being able to flow but presenting a white layer (Figure 2c), synonymous of segregation between solid and liquid phases forming the paste. For other cases, the paste was well formed but the segregation was noticed at the time of the measurement of the spreading out diameter: bubbles appear on the surface of wafer. Figure $2 d$ shows a well formed and homogeneous wafer, reserved to measure spreading out diameters and flow time. The same procedure will be followed during the experimentation; only mixtures not presenting any anomaly are retained for measurements.

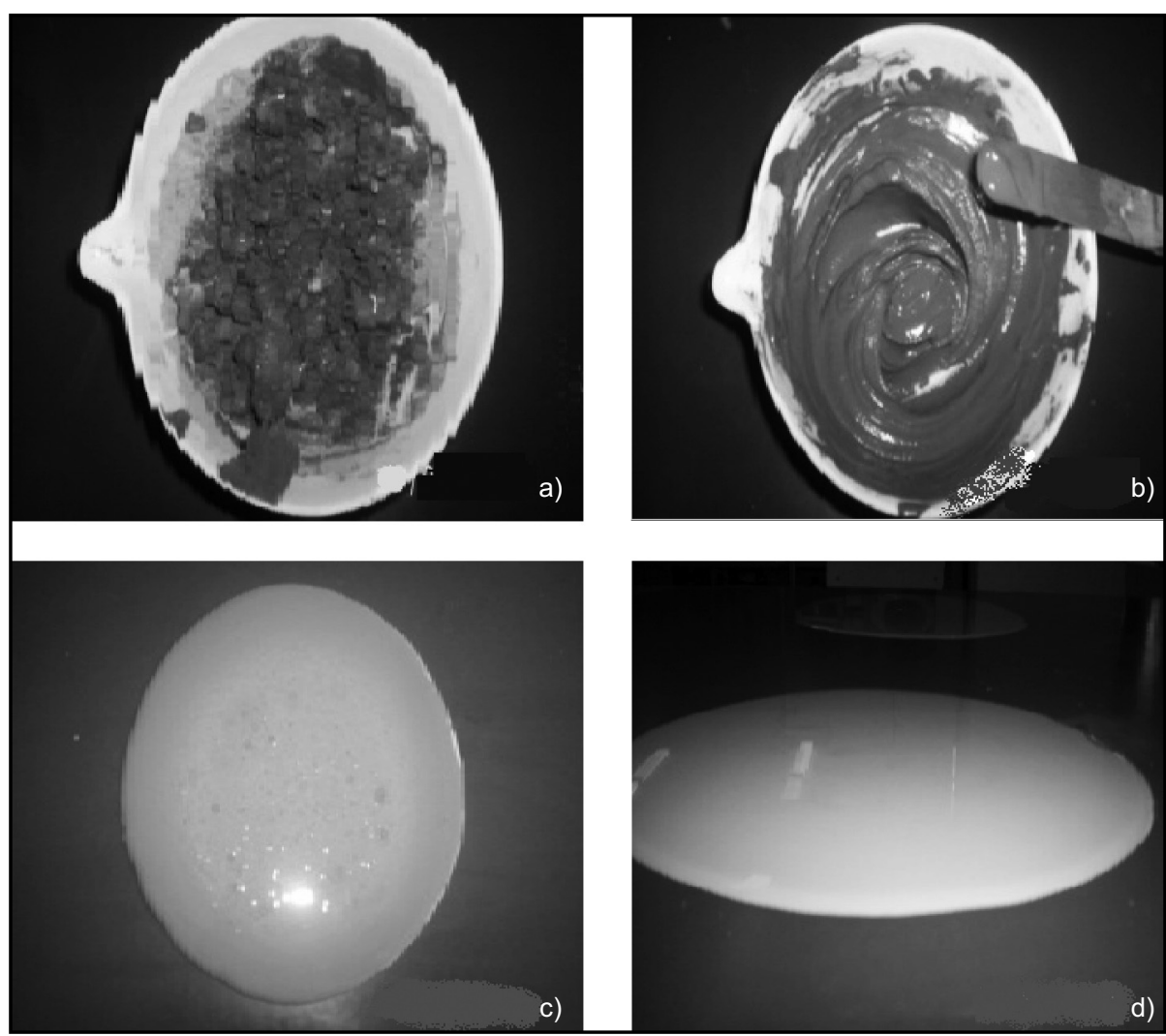

Figura 2. Aspectos visuales de las pastas elaboradas. Figure 2. Visual aspects of the elaborate pastes.

\subsection{Diseño estadístico de mezclas de las pastas de cemento}

\subsection{1. Área de experimentación}

Las mezclas de consistencia normal (aceptable) han servido para efectuar medidas reológicas y han contribuido a delimitar un dominio experimental dentro del

\subsection{Experimental plans for cement pastes}

\subsubsection{Experimental work}

Several mixtures of normal consistencies (acceptable) were useful for rheological measurements and contributed to the delimitation of an experimental field inside of which these 
cual estas medidas proporcionan los resultados deseados. Sus características básicas son: un diámetro de escurrimiento dentro del rango [14,4-16 mm] de acuerdo a la bibliografía (11) y un flujo sin rotura del volumen de pasta, característica de buena fluidez. El análisis de estos parámetros permite estudiar el efecto de cada elemento constitutivo de las suspensiones fluyentes y de la pasta confeccionada. Sin embargo, ha sido identificado un parámetro importante, se trata de la concentración volumétrica de sólidos $(\Gamma)$ definida por el cociente entre el volumen de los sólidos y el volumen total (partículas sólidas derivadas del cemento, del filler calizo y del superplastificante en forma seca). La utilización del diseño estadístico de mezclas contribuye a dar el máximo de información de los constituyentes, sus efectos tomados individualmente y sus eventuales interacciones. Asimismo, se permite reducir considerablemente el número de ensayos necesarios para planificar y facilitar el estudio. El objeto es conseguir las mezclas adecuadas para obtener las respuestas óptimas respondiendo a ciertas exigencias fijadas en un principio (12). La respuesta buscada depende de las proporciones volumétricas, la suma ha de ser igual a la unidad, lo que significa que los parámetros son dependientes unos de otros.

La relación siguiente da el dominio experimental ecuación. [1]: measurements give desired results. It is a bout aiming a spreading out diameter included in the interval [14.4 - 16 $\mathrm{mm}]$ in accordance with what was found in the literature (11) and with a flow without rupture of paste volume, characteristic of good fluidity. Parametric analysis allows understanding the importance of each mix parameter on the fluid suspensions and the made paste. However, an important parameter was introduced, it is the solid volumetric concentration $(\Gamma)$ defined by the report of solids volume on total volume (solid particles coming from cement, limestone filler and superplasticizer in dry extract form). The use of the experimental plans method contributes to give the maximum information about components, their influences taken separately and about their possible interactions. It makes possible to reduce considerably the number of experiments, to plan and facilitate the study. The objective is to obtain mixtures having of the optimal answers (results), or answering to certain requirements fixed upon the departure (12). For that, a wide variation of combinations between mixing parameters was used like preliminaries tests to select pastes with acceptable characteristics, the use of the experimental plans method shows that it is possible to delimit an experimental field bounded by the volumetric proportions of materials composing the paste. The field was transformed in equations form conditioned by implicit constraints, defining zones of minimal shearing threshold and maximum viscosity. The required answer depends on the volumetric proportions of the components used, their amount is equal to the unit, which wants to say that they are dependent the ones on the others.

The experimental field is constrained by the following relation [eq.1]:

$$
C+F+E+S p=1
$$

Donde: C: Cemento, F: Filler calizo, E: Agua, Sp: Superplastificante.

Considerando una mezcla completa, teniendo en cuenta la precisión deseada para la respuesta y del número de ensayos a desarrollar, el modelo matemático elegido converge hacia un polinomio de grado 2, relacionando la respuesta $\mathrm{Y}$ ( $\mathrm{Y}$ 1 para el diámetro de escurrimiento o $\mathrm{Y} 2$ para el tiempo de flujo) con las proporciones de los constituyentes en la forma siguiente ecuación [2]:
Where: C: Cement, F: Limestone, E: Water, Sp: Superplasticizer.

By considering a complete mixture plan, holding account of the desired precision of the response and the number of admitted experiments, the choice of a mathematical model converges towards a polynomial of degree 2, connecting the response $Y$ ( $Y 1$ for spreading out diameter or $Y 2$ for flow out time of) to the proportions of the components, which is written in the following form [eq. 2]:

$$
Y=\sum_{i=j}^{k} \beta_{i} \cdot X_{i}+\sum_{i<j}^{k} \sum_{j}^{k} \beta_{i j} \cdot X_{i} \cdot X_{j}
$$

Los coeficientes del polinomio $\beta_{\mathrm{i}}$ y $\beta_{\mathrm{ij}}$ a determinar son distintos para cada respuesta. Los parámetros $X_{i}$ y $X_{j}$
The polynomial coefficients $\beta_{i}$ and $\beta_{i j}$ are to be determined and are different for each answer. Parameters $X_{i}$ and $X_{j}$ 
corresponden a las proporciones volumétricas de los constituyentes ecuación [3]. correspond to the volumetric proportions of the components [eq. 3].

$$
\begin{gathered}
\mathrm{Y}=\beta_{1} \cdot \mathrm{C}+\beta_{2} \cdot \mathrm{F}+\beta_{3} \cdot \mathrm{E}+\beta_{4} \cdot \mathrm{Sp}+\beta_{12} \cdot \mathrm{C} \cdot \mathrm{F}+\beta_{13} \cdot \mathrm{C} \cdot \mathrm{E}+\beta_{23} \cdot \mathrm{F} \cdot \mathrm{E}+ \\
\beta_{14} \cdot \mathrm{C} \cdot \mathrm{Sp}+\beta_{24} \cdot \mathrm{C} \cdot \mathrm{Sp}+\beta_{34} \cdot \mathrm{F} \cdot \mathrm{Sp}
\end{gathered}
$$

En forma matricial, la relación (2) se escribe ecuación [4]: $\quad$ In matrix form, the equation (2) is written [eq. 4]:

$$
[Y]=[X][\beta]+[\varepsilon]
$$

Donde: $[\mathrm{X}]$ es la matriz de ensayo, $[\beta]$ es un vector columna con los coeficientes del modelo y $[\varepsilon]$ es un vector columna con los errores experimentales.

Los valores límite de cada parámetro son los siguientes ecuación [5]:
Where: $[X]$ is the experiment matrix, $[\beta]$ vector column of the model coefficients of the and $[\varepsilon]$ the vector column of the experimental errors.

The limit values of each parameter are [eq. 5]:

$$
\begin{gathered}
10 \% \leq \mathrm{F} \leq 20 \% \\
1 \% \leq \mathrm{Sp} \leq 1.5 \% \\
0.24 \% \leq \mathrm{E} /(C+F) \leq 0.3 \% \\
0.57 \% \leq \Gamma \leq 0.59 \%
\end{gathered}
$$

Donde: $(\Gamma)$ es la concentración volumétrica de sólidos.

La transformación de estas relaciones en ecuaciones aritméticas proporciona las expresiones de la ecuación [6]:
Where: $(\Gamma)$ is the volume concentration in solids.

The transformation of these constraints to equations form allows modeling the experimental problem in numerical type in order to find simply the required solutions [eq. 6].

$$
\begin{gathered}
C+F+E+S p=1 \\
-0,1125 C+F \geq 0 \\
0.2250 C-F \geq 0 \\
-0.0290 C-0.0258 F+S p \geq 0 \\
0.0435 C+0.0387 F-S p \geq 0 \\
0.43 C+0.43 F-0.17 S p-0.57 E \geq 0 \\
-0.41 C-0.41 F+0.19 S p+0.59 E \geq 0
\end{gathered}
$$

Para la determinación de los términos de la ecuación [6] se ha seguido el procedimiento que, a modo de ejemplo, se presente seguidamente, tomando como:

MF: Masa de filler calizo, MC: masa del cemento, $V F \equiv F$ : volumen filler calizo, $\mathrm{VC} \equiv \mathrm{C}$ : volumen de cemento.
In what follows, an example of calculation showing obtaining the equations of the system [6] is given:

MF: Mass of limestone, MC: mass of cement, $V F \equiv F$ : volume of limestone, $V C \equiv C$ : volume of cement.

$$
\begin{aligned}
& \text { Filler calizo / Limestone } \leq 20 \% \Leftrightarrow \frac{\mathrm{MF}}{\mathrm{MC}} \leq 0 \Leftrightarrow \frac{\mathrm{MF}}{\mathrm{MC}}-0.2 \leq 0 \\
& \frac{\mathrm{VF}}{\mathrm{VC}}=\frac{\frac{\mathrm{MF}}{2800}}{\frac{\mathrm{MC}}{3150}}=\frac{\mathrm{MF}}{\mathrm{MC}} \cdot \frac{3150}{2800} \rightarrow \frac{\mathrm{MF}}{\mathrm{MC}}=\frac{\mathrm{VF}}{\mathrm{VC}} \cdot \frac{2800}{3150}=\frac{\mathrm{VF}}{\mathrm{VC}} \cdot 0.889 \\
& \frac{\mathrm{VF}}{\mathrm{VC}} \cdot 0.889-0.2 \leq 0 \Leftrightarrow \mathrm{VF}-0.225 \cdot \mathrm{VC} \leq 0 \\
& 0.225 \cdot \mathrm{C}-\mathrm{F} \geq 0 \text { Ecuación tercera del sistema / Third equation of the system [6] }
\end{aligned}
$$


La Tabla 6 presenta las soluciones obtenidas en la ecuación [6]. Se aportan los valores máximos y mínimos para componente:
Table 6 gives the solutions calculated by excess and defect illustrated in the form of higher constraints and of lower constraints respectively.

Tabla 6 / Table 6

Valores extremos para cada componente.

Maximum and minimum values for each component.

\begin{tabular}{|c|c|c|c|c|}
\hline Componente / Component & C & F & Sp & E \\
\hline Valor máximo / Maximum value & 0.5159 & 0.1150 & 0.0246 & 0.4198 \\
\hline Valor mínimo / Minimum value & 0.4491 & 0.0568 & 0.0160 & 0.4033 \\
\hline
\end{tabular}

Para un diseño estadístico de mezclas con cuatro factores, el dominio de estudio constituido es un espacio con cuatro dimensiones. Los puntos de cálculo del modelo y de determinación de la matriz de ensayo forman un hiperpoliedro. Estos puntos están situados en los vértices, en el medio de los ejes, en el medio de las caras, y en el centro de gravedad. Teniendo en cuenta la complejidad de resolución del problema, una resolución clásica resulta casi imposible. Existen muchos paquetes de tratamiento del diseño estadístico de mezclas, entre otros "NemrodW" (12), desarrollado por la empresa LPRAI para la concepción y la planificación del plan de experimentación.

\subsubsection{Matriz de ensayos}

La determinación de la matriz de ensayos pasa por el análisis del algoritmo de cambio generado por el programa, que es un procedimiento aplicado a un número de variables desde $\mathrm{N}=10$ (número de coeficientes del polinomio) hasta $\mathrm{N}=\mathrm{N}_{\max }$ dependiente de los criterios de optimización:

- Criterio D: optimización de la calidad de la información.

- Criterio A: optimización de la calidad de los coeficientes del modelo.

- Criterio G: optimización de la calidad de previsión del modelo.

Una vez determinada la matriz de base, el siguiente objetivo es la determinación de los coeficientes del polinomio, los cuales son diferentes para cada caso. La Tabla 7 presenta la información necesaria para la
For an experimental plan with 4 factors, the field formed is a space with 4 dimensions. Model calculation points make the experiment matrix and form a hyper polyhedral. These points are located on the tops, in the mediums of the borders, in the mediums of the faces and in the centre of gravity. A traditional resolution is almost impossible with this complex problem, numerous are the softwares of treatment of experimental plans of mixtures, among them NemrodW (12), developed for the design and the analysis of experimental plans.

\subsubsection{Test matrix}

The determination of the experiment matrix passes by the analysis by the exchange algorithm generated by the software, which is a procedure applied to $N=10$ of variables (number of polynomial coefficients) until $N=N m a x$ corresponding to satisfaction of the following optimization criteria:

- Criterion D: optimization of information quality.

- Criterion A: optimization of model coefficients quality.

- Criterion G: optimization of model forecast quality.

Once determined, the basic matrix has as a postulated objective the determination of polynomial coefficients of the model which are different for each answer. Table 7 below gives necessary information about experiment

Tabla 7 / Table 7

Características del problema.

Characteristics of the problem.

\begin{tabular}{|c|c|}
\hline Objeto del estudio / Aim of the study & Estudio de las mezclas / Mixing study \\
\hline Nombre de las variables / Number of variables & 4 \\
\hline Nombre de las experiencias / Number of experiments & 35 \\
\hline Nombre de los coeficientes / Number of coefficients & 10 \\
\hline Nombre de las respuestas / Number of answers & 2 \\
\hline
\end{tabular}


construcción de la matriz de ensayos, así como las principales características del problema estudiado, generado por el programa NemrodW.

La Tabla 8 presenta las características de la matriz de ensayos. Estos valores han sido generados por el software y son utilizados para el campo experimental. matrix and principal characteristics of the studied problem; these informations are generated by the NemrodW software.

Table 8 gives the characteristics of the experiment matrix made up of the voluminal proportions of the components to be used in the preparation of the cement pastes. These values are generated by the software and are taken inside the experimental field.

Tabla 8 / Table 8

Características de la matriz de ensayos.

Characteristics of the experiment matrix.

\begin{tabular}{|c|c|}
\hline Propiedades / Properties & Valores / Values \\
\hline Determinante $\left(\mathrm{X}^{\prime} \mathrm{X}\right)^{1 / \mathrm{p}} /$ Determinant $\left(\mathrm{X}^{\prime}\right)^{1 / / p}$ & 3.9588 \\
\hline Determinante $(\mathrm{M}) /$ Determinant $(M)$ & $5.5578975 \mathrm{E}-0017$ \\
\hline Determinante $(\mathrm{M})^{1 / \mathrm{p}} /$ Determinant $(M)^{1 / p}$ & 0.082476 \\
\hline Función maxima / Function of maximum variance & 0.333333 \\
\hline Traza $\left(\mathrm{X}^{\prime} \mathrm{X}\right)^{-1} /$ Trace $\left(\mathrm{X}^{\prime} \mathrm{X}\right)^{-1}$ & 6.0948 \\
\hline Eficacia G $(\%) /$ Effectiveness $\mathrm{G}(\%)$ & 93.75 \\
\hline Índice de Khuri $(\%) /$ Index of Khuri (\%) & 97.85 \\
\hline
\end{tabular}

Teniendo en cuenta los valores de las proporciones volumétricas generados por el programa NemrodW se prepararán las mezclas y los resultados obtenidos se introducirán de nuevo en el programa para definir los valores óptimos de la proporciones de cemento, piedra caliza, superplastificante y agua. La Figura 3 muestra el diagrama ternario en el espacio (parte izquierda) y en el plano (parte derecha) presentando el efecto de cada constituyente en la mezcla de la pasta. Fijando, un constituyente y variando los otros tres, su suma debe ser igual a la unidad. Igualando el parámetro "agua" a 0,305 por ejemplo, y variando las proporciones volumétricas de los otros componentes, el parámetro "Sp" es preponderante; las respuestas serán más sensibles a las variaciones de este parámetro que a la del "cemento" o la de la "filler calizo", habrá más interacciones entre "Sp" y el "cemento", debido a que el dominio de influencia está más cercano del cemento que del filler calizo. El mismo estudio se ha realizado sobre la respuesta frente a la fluencia (fluidez) Figura $3 a$.

\subsubsection{Respuestas experimentales}

Al final del estudio, se han elaborado las curvas siguientes para $\Gamma=0,58$ (Figura 4). En la Figura $4^{a}$ se observa que una tasa del $15 \%$ de piedra caliza permite disminuir el límite de corte, mientras que la curva $4 \mathrm{~b}$ muestra que una dosificación de 1,5\% de superplastificante permite aumentar la viscosidad. Estos dos aspectos reológicos complementarios definen el carácter autocompactante de la pasta. Los valores de Sp y de la relación $(F / C)$ están rodeados por un círculo negro en las curvas para las dos
When the software provided the volumetric values of composition parameters, those are used to prepare the pastes on which measurements will be taken. The measured answers (spreading out diameters, flow times) will be again introduced to the software like new data, in order to define the optimal proportion values of cement, limestone filler, superplasticizer and water. Figure 3 gives ternary diagrams, in space and in the plan illustrating the influence of each parameter on the paste mixture. Indeed, by fixing one parameter and while varying the three others, their sum should to be equal to the unit. By fixing the parameter "water" at 0.305 for example, and while varying the voluminal proportions of the others components, the parameter "Sp" is dominating: answers are more sensitive to the variations of this parameter than to those of "cement" or of the "filler", there would be interactions between "Sp" and "cement", following the site of the field of influence which is closer to cement than filler, Figure $3 a$.

\subsubsection{Experimental results}

At the end of the treatment, the curves below worked out for $\Gamma=0.58$, (Figure 4). Figure $4 a$ shows that substitution of $15 \%$ of limestone filler decrease the threshold of shearing, whereas Figure $4 b$ shows that a proportioning of $1.5 \%$ of superplasticizer increase viscosity. These two complementary rheological aspects define the required self-compacting cement paste property. The values of $S p$ and $(F / C)$ checking these two properties are surrounded by black circles in the graphs 


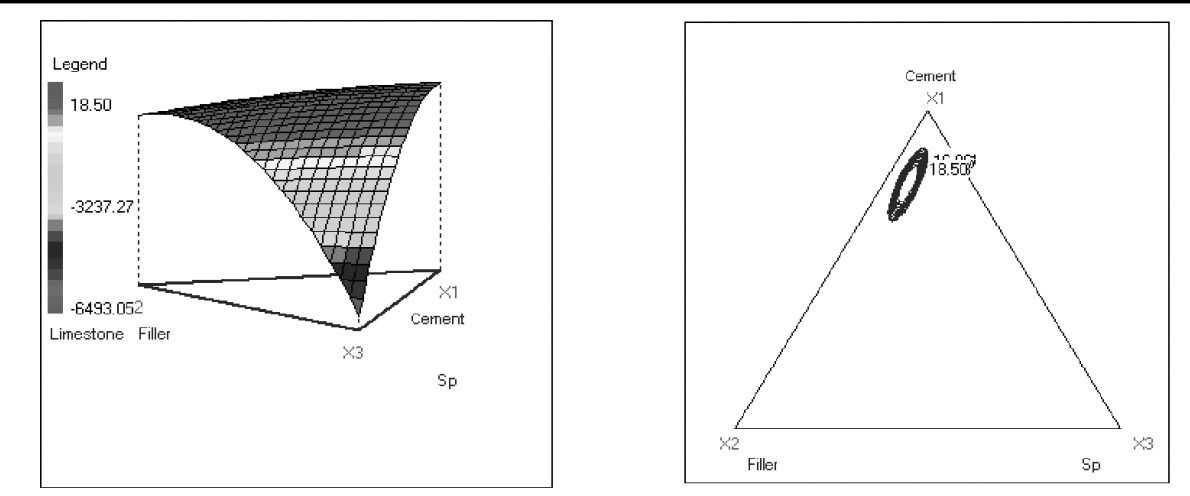

a) Variación de la respuesta cemento-piedra caliza-Sp; agua $=0,305$

a) Variation of the answer spreading out in the plan Cement-Filler-Sp; Water $=0.305$.
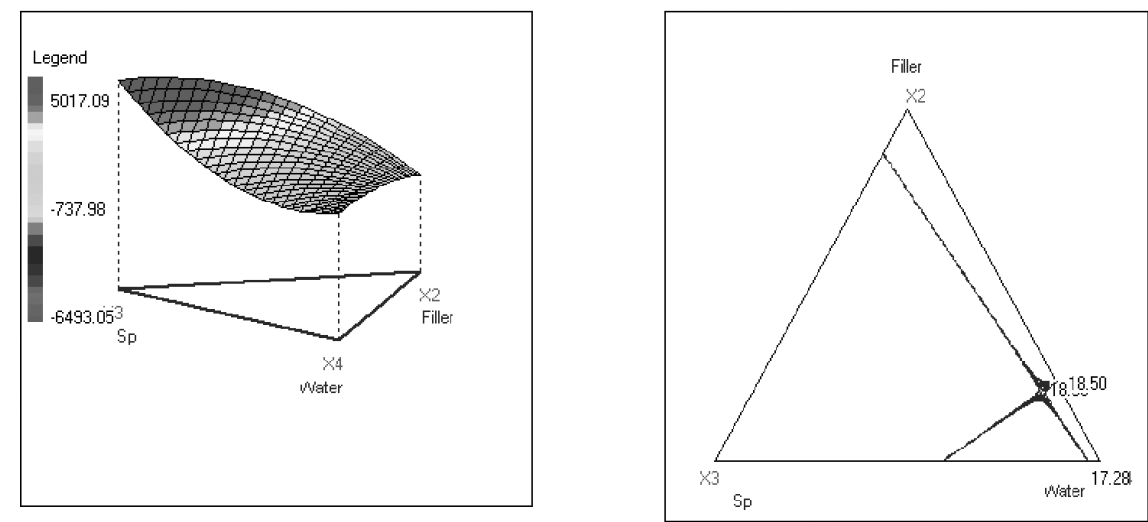

b) Variación de la respuesta piedra caliza-Sp-agua; cemento $=0,511$.

b) Variation of the answer spreading out in the plan Filler-Sp-Water; Cement $=0.511$.
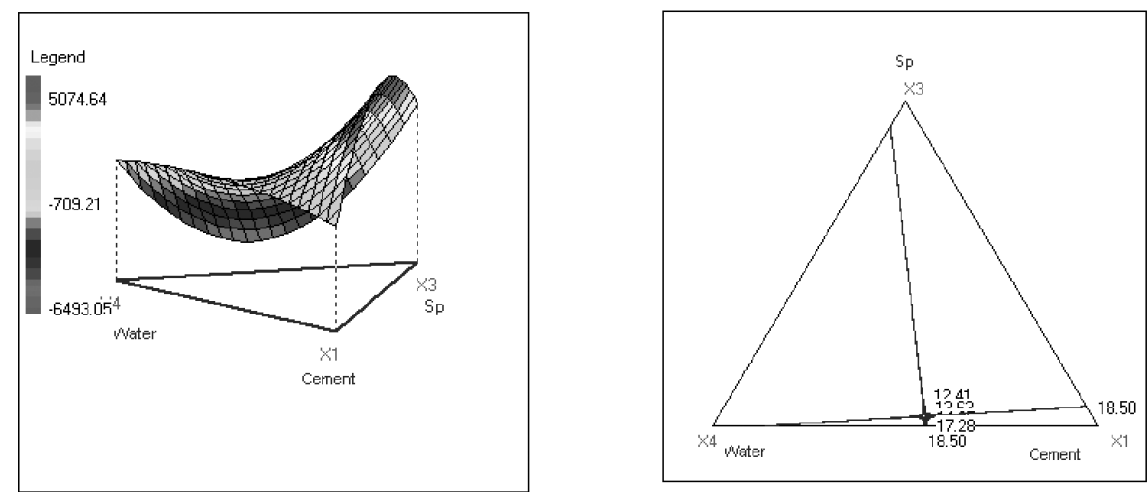

c) Variación de la respuesta Sp-agua-cemento; piedra caliza $=0,112$

c) Variation of the answer spreading out in the plan Sp-Water-Cement; Filler $=0.112$.

Figura 3. Diagrama ternario de la respuesta.

Figure 3. Ternary diagrams for the answer spreading out.

respuestas. Al igual que en el caso de V. Boel (13), las dos propiedades importantes "alta fluidez y resistencia a la segregación" han sido obtenidas con el empleo de un superplastificante y añadiendo finas partículas (piedra caliza) sin el uso adicional de modificadores de la viscosidad. of the two answers. As obtained in V. Boel et al. study (13), the two essential properties "high flow ability and segregation resistance" have been obtained with use of superplasticizer and fine particles (limestone filler) and without use of a viscosity modifying admixture 


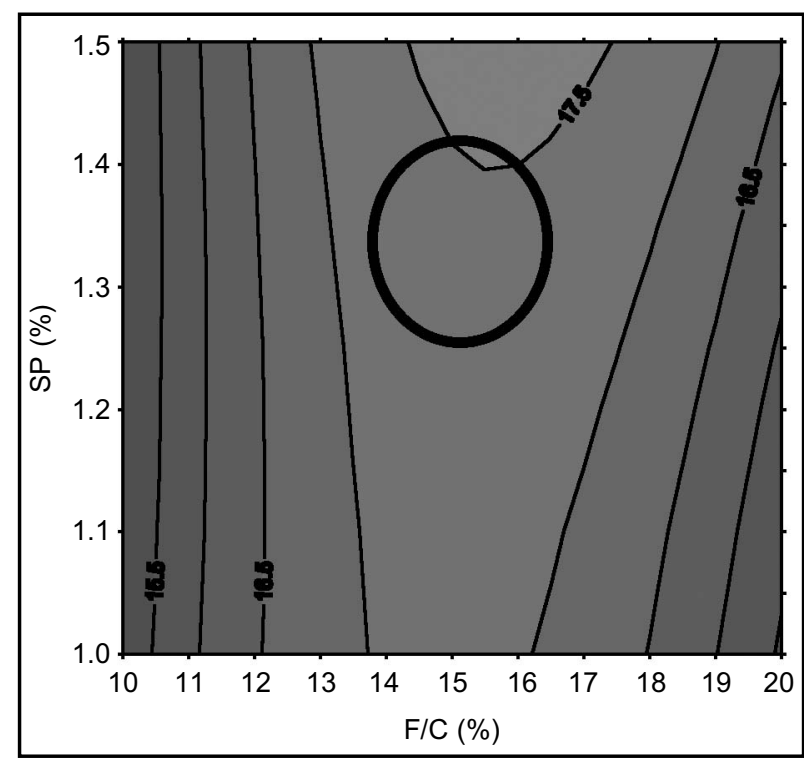

Figura 4a. Diámetro de escurrimiento para $\Gamma=0,58$. Figure 4a. Spreading out for $\Gamma=0.58$.

Las características estadísticas de estas dos respuestas están representadas en la Tabla 9.

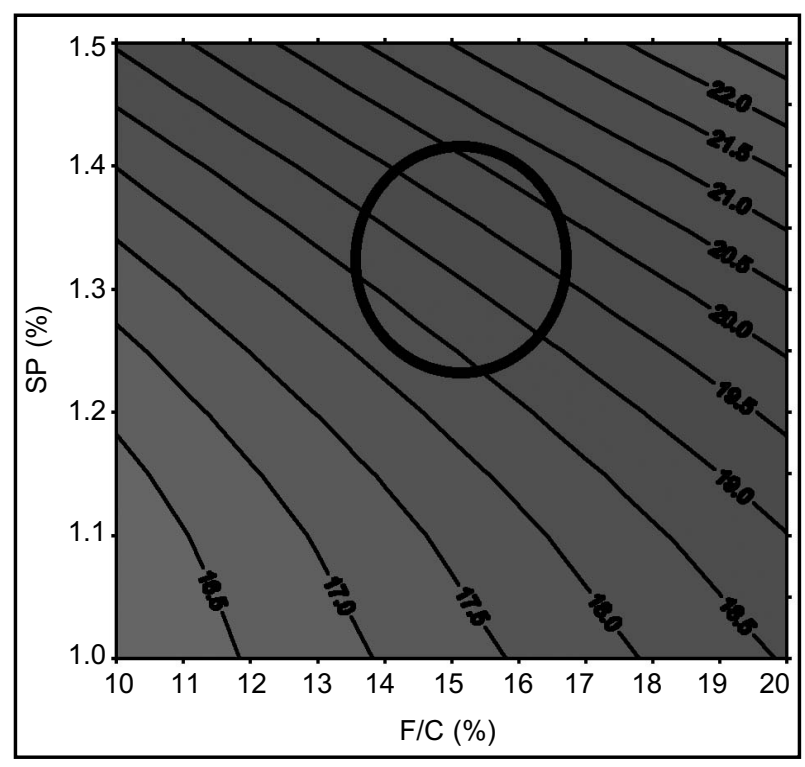

Figura 4b. Tiempo de fluidez para $\Gamma=0,58$. Figure $4 b$. Flow Time for $\Gamma=0.58$.

The statistical characteristics of these two answers are given in Table 9.

Tabla 9 / Table 9

Características de la matriz de ensayos. Characteristics of the answers.

\begin{tabular}{|c|c|c|c|c|c|}
\hline Respuesta / Answer & Media / Average & Desviación / Type - gap & Mínimo / Minimum & Máximo / Maximum & Valor central / Center \\
\hline $\begin{array}{c}\text { Escurrimiento (cm)/ } \\
\text { Spreading out (cm) }\end{array}$ & 18.377 & 2.275 & 13.600 & 23.000 & 18.300 \\
\hline $\begin{array}{c}\text { Tiempo de flujo (s)/ } \\
\text { Time flow (s) }\end{array}$ & 12.217 & 2.444 & 8.000 & 18.000 & 13.000 \\
\hline
\end{tabular}

\subsection{Pasta óptima}

La utilización de un paquete de tratamiento del diseño estadístico de mezclas permite obtener dos respuestas simultáneamente. Es un procedimiento numérico que consiste en buscar matemáticamente una combinación de parámetros (formulación) para la cual las respuestas deseadas dan valores óptimos, o fijan un intervalo de valores óptimos; es el caso de una optimización multicriterio basándose en las funciones de conveniencia. El paquete utilizado emplea estas funciones y para cada respuesta, se elige un perfil de curva de la función de conveniencia, Figura 5. La conveniencia es nula para una respuesta no adecuada y es máxima cuando la respuesta dada es muy satisfactoria, se toman los valores intermedios para las respuestas más o menos satisfactorias. La conveniencia global exigida Dg(pasta) para la pasta óptima requerida es función de las conveniencias elementales, $d$ (escurrimiento) y $d$ (flujo) respectivamente, exigidas para el escurrimiento y el tiempo de fluidez y está definida por la relación ecuación [7]:

\subsection{Optimal paste}

Digital treatment of the experimental plans allows to optimize simultaneously two answers, it is a purely numerical procedure consisting in mathematically seeking a combination of parameters (formulation) for which the desired answers are either of the optimal values, or belonging to an interval of optimal values; it is the multi-criterion case of an optimization which is based on desirability function. Using these functions to resolve postulated problem: for each answer, a profile of curve of the desirability function is selected, Figure 5. The desirability is null for a nonsuitable answer and is maximum when the answer given is very satisfactory, it takes intermediate values for answers at least satisfactory. The total desirability required Dg (paste) for the required optimal paste is a function of the elementary desirabilities $d$ (spread) and $d$ (flow) respectively required for spreading out and flow out time, it is defined by the relation [eq. 7]: 


$$
\operatorname{Dg}(\text { pasta })=\sqrt{(\mathrm{d}(\text { expansión } \cdot \mathrm{d}(\text { fluidez }))}
$$

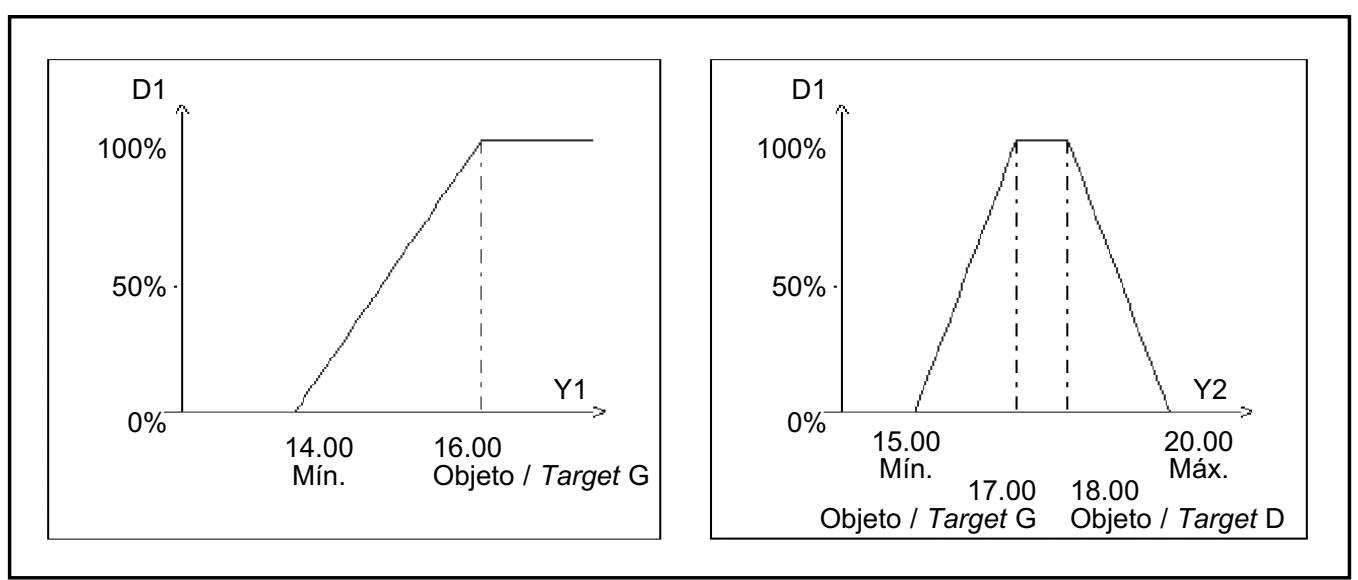

Figura 5. Curvas de las funciones de conveniencia.

Figure 5. Graphs of desirability functions.

La Figura 5 presenta las curvas de las funciones de conveniencia elegidas. Es de tipo unilateral derecho, sin tolerancia para las respuestas $\mathrm{Y} 1$ (escurrimiento) y de tipo bilateral con tolerancia para Y2 (tiempo de fluidez). A partir de esta opción, la Tabla 10 muestra las características de las funciones de las conveniencias elementales y de la función de conveniencia global definida por la relación [7]. La conveniencia buscada es $d_{i}$, para ello se han de buscar los valores idóneos de fluidez y escurrimiento. Se han hecho varias tentativas para distintos valores de $d_{i}(52,63,77,100 \%)$, resultando que ciando $d_{i}$ coincide con $d_{i m a x}$ el resultado fue el óptimo.
Figure 5 shows the graphs of the functions of desirability chosen, it is of unilateral type right without tolerance for the $Y 1$ answers (spreading out) and of bilateral type with tolerance for $Y 2$ (time of flow). On the basis of this choice, Table 10 gives the characteristics of the elementary functions of desirability and the function of total desirability defined by the relation [7].

Tabla 10 / Table 10

Características de las funciones de conveniencia. Characteristics of desirability functions.

\begin{tabular}{|c|c|c|c|c|c|}
\hline Respuesta / Answer & Valor / Value & di \% & Peso / Weight & di mín. \% / di min \% & di máx. \% / di max \% \\
\hline Expansión / Spreading out diameter & $17.15 \mathrm{~cm}$ & 100.00 & 1 & 65.31 & 100.00 \\
\hline Fluidez / Flow time & $15.75 \mathrm{~s}$ & 100.00 & 1 & 100 & 100.00 \\
\hline Conveniencia (Dg) / Desirability (Dg) & & 100.00 & & 80.82 & 100.00 \\
\hline
\end{tabular}

Tomando en cuenta los criterios de conveniencia relativos a la homogeneidad y a la fluidez de la pasta se ha determinado la pasta óptima. La Tabla 11 muestra los valores de los constituyentes de esta pasta.
By answering to desirability criterion relating to the paste homogeneity and fluidity, after treatment by software, the formulation of the optimal paste was given. Table 11 gives volume proportions and dosages of each paste component.

Tabla 11 / Table 11

Composición de la pasta óptima.

Composition of the optimal paste.

\begin{tabular}{|c|c|c|}
\hline Composición / Component & Proporción volumétrica / Volume proportions & Dosificación (g/l) / Dosage (g/l) \\
\hline Cemento / Cement & 0.538 & 1694.7 \\
\hline Piedra caliza / Limestone & 0.116 & 324.8 \\
\hline Sp & 0.014 & 15.19 \\
\hline Agua / Water & 0.332 & 3320 \\
\hline
\end{tabular}


Con las proporciones obtenidas, la pasta de cemento ha sido elaborada con objeto de comprobar los resultados teóricos. Visualmente, el aspecto de la pasta obtenida era aceptable, sin presentar aparentemente segregación. La Tabla 12 muestra los resultados experimentales de los diámetros de escurrimiento y del tiempo de flujo. A partir de los resultados, se han notado pequeñas diferencias entre los valores teóricos y experimentales, del orden de $0,05 \mathrm{~cm}$ para los diámetros de escurrimiento y 0,11 s para el tiempo de flujo, esto significa que el modelo obtenido es válido. La continuación de este trabajo consiste en inyectar los áridos al mismo tiempo (grava y arena para un cociente fijo $\mathrm{G} / \mathrm{S}$ ) y agua para alcanzar la fluidez deseada con el fin de obtener un hormigón autocompacto, comprobando sus características en estado fresco según la recomendación francesa de construcción.
With the proportions obtained, a cement paste was elaborated in order to check, to compare then to validate theoretical results obtained. Visually, paste aspect was acceptable without presenting any apparent segregation. Table 12 gives experimental results measurement of spreading out diameter and flow time. Small difference between theoretical an experimental values, about 0.05 $\mathrm{cm}$ for spreading out diameter and $0.11 \mathrm{~s}$ for flow time, it means that model proposed can be validated. The continuation of work consists to inject aggregates at the same time (sand and gravel for fixed ratio $G / S$ ) and to balance with water to reach desired fluidity. With the end of the procedure, a self consolidating concrete could be obtained while checking its characteristics in a fresh state according to the recommendation of the French association of civil engineering.

Tabla 12 / Table 12

Comparación de los resultados teóricos y experimentales. Theoretical - experimental results comparison.

\begin{tabular}{|c|c|c|}
\hline & $\begin{array}{c}\text { Diámetro de escurrimiento }(\mathbf{c m}) \text { / } \\
\text { Spreading out diameter (cm) }\end{array}$ & Tiempo de fluidez (s) / Flow time \\
\hline Valor objeto / Target values & $\geq 14.00$ & $15.00 \leq$ tiempo / time $\leq 20.00$ \\
\hline Valores teóricos / Theoretical values & 17.15 & 15.75 \\
\hline Valores experimentales / Experimental values & 17.20 & 15.86 \\
\hline
\end{tabular}

\section{CONCLUSIONES}

Este estudio trataba de conseguir la formulación de una pasta autocompactante a base de materiales locales argelinos. Se consiguió determinar la composición de la pasta óptima, la cual, añadida a las partículas proporciona un hormigón con propiedades autocompactantes. El estudio, apoyado en un diseño estadístico de mezclas aplicado a las pastas de cemento, permitió definir un dominio experimental en el cual todas las mezclas presentan unas características medibles. El número de los ensayos se ve considerablemente reducido, en comparación con los métodos de formulación tradicionales. Se elaboró una matriz de ensayos que responde a los criterios de optimización (criterios $D, A$ y $G$ ) para determinar los coeficientes (relativos a cada respuesta) del modelo postulado. El programa NemrodW sirvió para dibujar los diagramas ternarios que mostraron la existencia de interacciones entre los constituyentes tomados de dos en dos. Una conveniencia global muy satisfactoria del $100 \%$ ha permitido definir una formulación de pasta autocompactante dentro del dominio experimental.

\section{CONCLUSIONS}

In this work the formulation of a self-compacting paste with Algerian materials has been carried out. An extensive experimental program has been carried out, applying a new paste concept for self-compacting concrete (SCC), which consider that fresh concrete selfcompacting properties come from those of the cement paste. A study by experimental plans method applied to the cement pastes enabled to give maximum information about components, their influences taken separately and about their possible interactions. It permitted to define an experimental field in which all mixtures showed measurable characteristics, to reduce considerably the number of experiments, to plan and to facilitate the study. It allowed to build an experiment matrix and to propose formulations according to fixed target values. Simply, by measurement of the spreading out diameters and flow times, an optimal paste proportioning was elaborated, which combines the criteria for low shear strengths, high viscosity and optimum flow-viscosity ratio of paste, was developed and validated by experiences measurements checking. Numerical model postulated, obtained a total desirability of $100 \%$, thus very satisfactory allowed defining a formulation of a self - compacting paste inside the experimental field. 


\section{BIBLIOGRAFÍA / BIBLIOGRAPHY}

(1) Xie, Y.; Liu, B.; Yin, J.; Zhou, S.: "Optimum mix parameters of high-strength self-compacting concrete with ultrapulverized fly ash", Cem. Concr. Res., vol. 32, Issue 3 (2002), pp. 477-480. doi:10.1016/S0008-8846(01)00708-6

(2) Naadia, T.; Mouret, M.; Kharchi, F.: "Effect of the size on the rheological behaviour of the concretes. Application to the SCC", $1^{\text {st }}$ International Conference on the Technology and the Durability of Concretes CITDUB1, USTHB, Algiers, Algeria (2004).

(3) Kantro, D. L.: "Influence of water-reducing admixtures on properties of cement paste -a miniature slump test", Cement, Concrete and Aggregates, vol. 2, Issue 2 (1980), pp. 95-102.

(4) Cyr, M.: "Contribution à la caractérisation des fines minérales et à la compréhension de leur rôle joué dans le comportement rhéologique des matrices cimentaires", Thesé en cotutelle INSA de Toulouse (France) et Université de Sherbrooke (Canada) (1999).

(5) Roussel, N.; Stefani, C.; Leroy, R.: "From mini-cone test to Abrams cone test: measurement of cement-based materials yield stress using slump tests", Cem. Concr. Res., vol. 35, Issue 5 (2005), pp. 817-822. doi:10.1016/j.cemconres.2004.07.032

(6) Zhor, J.; Bremner, T. W.: "Advances in evaluation of lignosulphonates and concrete admixtures," Proceedings of the Fourth CANMET/ACI/JCI International Conference, Ed. Mohan Malhota, Tokushima, Japan SP-179 (1998) pp. 1011-1042.

(7) Ferraris, Ch.; Obla, K. H.; Hill, R.: "The influence of mineral admixtures on the rheology of cement paste and concrete", Cem. Concr. Res., vol. 31, Issue 2 (2001), pp. 245-255. doi:10.1016/S0008-8846(00)00454-3

(8) Phan, T. H.; Chaouche, M.: "Rheology and stability of self-compacting concrete cement pastes", Applied Rheology, vol. 15, Issue 5 (2005), pp. 336-343.

(9) Bui, V. K.; Akkaya, Y.; Shahm, S.: "Rheological model for self-consolidating concrete", ACI Materials Journal, vol. 99 , Issue 6 (2002). (10) Ferrara, L.; Park, Y.-D.; Shah, S.: "A method for mix-design of fiber-reinforced self-compacting concretec, Cem. Concr. Res., vol. 37, Issue 6 (2007), pp. 957-971. doi:10.1016/j.cemconres.2007.03.014

(11) El Barrak, M.: "Contribution a l'etude de l'aptitude a l'ecoulement des betons autoplacants a l'etat frais". Doctorat These. Laboratoire Materiaux et Durabilite des Constructions, Université de Paul Sabatier, Toulouse III, France (2006).

(12) Mathieu, D.; Phan-Tan-Luu, R. ; Sergent, M.: Méthodologie de la recherche expérimentale. Criblage et étude des facteurs. LPRAI, Marsella (2000).

(13) Boel, V.; Audenaert, K.; Schutter, G.: "Pore size distribution of hardened cement paste in self compacting concrete. ACI SP 234-11 (2006), pp. 167-178. 